\title{
Impact of Cluster Frontline Demonstrations (CFLDs) on Pulse Production Productivity, Profitability and Transfer of Technologies in Kurnool District of Andhra Pradesh, India
}

\author{
Jayalakshmi Mitnala*, G. Prasad Babu, K. Ragavendra Chowdary, \\ B. Vijayabhinandana and M. Subba Rao \\ Krishivigyan Kendra Banavasi, Kurnool (Dis), Acharya N G Ranga \\ Agricultural University, India \\ *Corresponding author
}

\begin{abstract}
A B S T R A C T
The present study was carried out to evaluate the performance of improved cultivars with scientific package of practices on production, productivity and profitability of pulses.

Keywords

Cluster front line demonstration,

Production,

Productivity,

Extension gap,

Technology gap,

Technology index

Article Info

Accepted:

10 November 2018

Available Online:

10 December 2018

Cluster frontline demonstrations (CFLDs) were conducted during 2016-17 and 2017-18 in total of 170 demonstrations with evaluation of the performance of TBG 104, variety of blackgram in Orvakallu and Gonegandla blocks, Red gram variety PRG-176 in Mecadona block and Chick pea Variety NBeG-3 in Ramapuram block of the district and record the feedback information of farmers. The results revealed that average yield of red gram, black gram and chick pea under cluster frontline Demonstrations were 970,1160 and $850 \mathrm{Kgha}^{-1}$ as compare to 830,890 and $720 \mathrm{Kgha}^{-1}$ recorded in farmer's practice in 2016-17, and in 2017-18 the average yields were1050,1280 and $950 \mathrm{Kgha}^{-1}$ in demonstration fields where as $870,910,810 \mathrm{Kgha}^{-1}$ in farmer's practice. The average yield increase of $18.7,35.6$ and 19.93 per cent and additional return of 15,753.00, 21,308.00 and 7,743.00 Rs ha ${ }^{-1}$ respectively. It was observed that the benefit cost ratio (B: C) of recommended practice (CFLDs) were 2.1, 2.72 and 2.09 as compared to 1.40, 1.68 and 1.59 in farmer's practice. The average extension gap 160, 320 and $130 \mathrm{Kgha}^{-1}$, average technology gap 490,790 and $600 \mathrm{Kgha}^{-1}$ and technology Index 32.6, 64.3 and 61.3 were recorded. Therefore, the results clearly indicates that the use of improved varieties and package and practices with scientific intervention under frontline demonstration programme contribute to increase the productivity and profitability of pulses in Andhra Pradesh state.
\end{abstract}

\section{Introduction}

India's economy has been dominated by agriculture. However, Indian agriculture fiercely depends on monsoons to yield sufficient agricultural returns. India's major food crops rice and wheat have been heavily incentivized with MSP in addition to preferential treatment of Public Distribution System to benefit the Indian poor. Hence, Indian farmers are most motivated to grow either these crops or cash crops like cotton, sugarcane etc. Pulses have been a second choice for the farmers for cultivation. 
Over a period of time, a number of improved pulses varieties and production technologies have been developed, but full potential of these varieties as well as technologies could not be exploited due to low rate of adoption and low yields. Thus, factors limiting the productivity cannot be overlooked. Research and extension programmes need to be diverted to produce value additive pulses. It may emphasize on quality attributes, adoption and popularization of new agro technology, evolving better varieties for stress conditions and improving present yield potential. The aim of these demonstrations in general is to raise production through transfer of farm technology. The efforts were taken with planning, execution and follow up action of the pulses production technology through front line demonstrations (Sumathi, 2012).

Cluster front line demonstrations (CFLDs) is a novel approach to provide a direct interface between researcher and farmer for the transfer of technologies developed by them and to get direct feedback from farming community. To meet the growing demand for food grains, National Development Council (NDC) in its 53rd meeting adopted a resolution to enhance the production of rice, wheat and pulses by 10 , 8 and 2 million tons respectively by 2011 with an outlay of Rs. 4,882 crore under National Policy for Farmers in the Eleventh Five Year Plan. The proposed Centrally Sponsored Scheme 'National Food Security Mission (NFSM) is to operationalise the resolution of NDC and enhance the production of rice, wheat and pulses (Annonymous, 2011). The concept of Cluster first line demonstrations was put forth under this mission. The scheme implemented in a mission mode through a farmer centric approach. The scheme aims to target the select districts by making available the improved technologies like promotion of Integrated Nutrient Management (INM) Integrated Pest Management (IPM), promotion of micronutrients/gypsum/bio- fertilizers, promotion of sprinkler irrigation, and Extension, training and mass media campaign. These demonstrations are conducted under the close supervision of scientists of Krishi Vigyan Kendras, SAUs and their Regional Research Stations.

The major pulses producing states in India are Madhya Pradesh, Maharashtra, Rajasthan, Uttar Pradesh, Andhra Pradesh and Karnataka. These six states account for 79 percent of area and 80 percent of production of pulses in India. These pulses crops can be grown in kharif and rabi seasons in India and cultivated in marginal lands under rainfed conditions. Only 15 percent of area under pulses has assured irrigation. Among these six major pulses producing states in India, the productivity per hectare vary significantly from one state to another state. In Andhra Pradesh (13 districts) the area under pulses is 14.13 lakh hectares in 2016-17 which accounted for 2.8 per cent in total food crops area, whereas the same in 2011-12 is 13.38 lakh hectares which accounted for the same 2.8 per cent of total food crops area which is very slow or stagnated over 5 years.

Hence there is need for expansion of area and production in pulses in Andhra Pradesh. Cluster Front Line Demonstrations (CFLDs) under National Food Security Mission (NFSM) playing key role in introduction of improved varieties and production technologies in pulses.

\section{Materials and Methods}

Cluster frontline demonstrations were conducted by the Krishi Vigyan Kendra, Banavasi, Kurnool district of Andhrapradesh in kharif and Rabi seasons in the farmer's fields during 2016-17 and 2017-18 with evaluation the performance of new varieties and package of practices on production and productivity of pulses demonstrated for 
Redgram, Balack gram and Bengal gram were identified based on Participatory Rural Appraisal (PRA) technique. A group of cooperative farmers were identified based on their participation and feedback received during the preliminary survey and interactive meeting. All 170 demonstrations in 340ha area were conducted by the active participation of farmers with the objective to demonstrate the improved technologies of pulses production potential in different villages. A total area of 10-20 hectare in every year was fixed for the demonstration of technologies in Redgram, Black gram and Bengal gram along with farmers practice as control plot. Assessment of gap in adoption of recommended technology before laying out the cluster frontline demonstrations (CFLD's) through personal discussion with selected farmer's. The awareness programme (preseason training) was organized for selection of farmer's and skilled development about detailed technological intervention with improved package and practice for successful cultivation. Critical inputs for the technologies to be demonstrated (Table 1,2 and 3) were distributed to the farmers after the training like improved high yielding variety, recommended chemicals and literature and regular visit, monitoring and pest and disease advisory services management by the KVK scientist to the demo farmers. Finally field day was conducted involving demonstration holding farmers, other farmers in the village, Scientists from University and ATARI, officials from Department of Agriculture and local extension functionaries to demonstrate the superiority of the technology for each crop. Crop yield was recorded from the demonstration and control plots for the crops at the time of harvest. The most feasible way by which this could be achieved is by demonstrating the recommended improved technology on the farmer's fields through front line demonstrations with the objectives to work out the input cost and monetary returns between front line demonstration and farmers methods, to identify the yield gaps between farmer's practices and front line demonstrations. The basic information were recorded from the farmer's field and analyzed to comparative performance of cluster frontline demonstrations (CFLD's) and farmer's practice. The yield data were collected from both the demonstration and farmers practice by random crop cutting method and analyzed by using simple statistical tools. The technology gap and technological index (Yadav et al., 2004) were calculated by using following formula as given below

Extension gap $=$ Demonstrated yield- farmer's practice yield

Technology gap $=$ Potential yieldDemonstration yield

Additional return $=$ Demonstration return farmer's practice return

Technology index $=$

Potential yield-Demonstration yield $* 100$

Potential yield

Percent increase yield $=$

Demonstration yield - farmers yield X 100

Farmers yield

\section{Results and Discussion}

The improved package and practices is more important with technological intervention for productivity and profitability of pulses. Detailed package and practices with technological intervention for recommended practice (Table 1, 2 and 3). It was also observed that farmer's use injudicious and unrecommended insecticides and mostly didn't 
use fungicides. Similar observations were reported by Singh et al., (2011).

\section{Grain yield and gap analysis of red gram}

The grain yield and gap analysis of Red gram in demonstrated field's and farmer's practice is presented in table 4. Data revealed that average grain yield of demonstrated field's was higher from farmer's practice in both years. The results revealed that average grain yield of Red gram under cluster frontline demonstrations were 970 and $1050 \mathrm{Kg} \mathrm{ha}^{-1}$ as compare to 830 and $870 \mathrm{Kg} \mathrm{ha}^{-1}$ recorded in farmer's practice and average yield increase of 16.86 and 20.68 per cent, respectively. The above finding was in accordance with Singh et al., (2018). The extension gap 140 and $180 \mathrm{Kg}$ $\mathrm{ha}^{-1}$ technology gap 560 and $450 \mathrm{Kg} \mathrm{ha}^{-1}$ and technology index 35.3and 29.50 was recorded (Table 4). This Extension gap should be assigned to adoption of improved dissemination process in recommended practices which outcome in higher grain yield than the farmer's practice.

\section{Economics analysis of red gram}

Economic performance of red gram under cluster frontline demonstration was depicted in table 5. The economic analysis results revealed that the red gram recorded higher total return from recommended practice (CFLD's) were 48,985.00 Rsha-1 in 201617and 57,225 00 Rsha-1 in 2017-18 as compared to $24,335.00$ Rsha-1 and 26,980.00Rsha-1 farmer's. practice respectively. The net returns were $24,650.00$ Rsha-1 in 2016-17 and 30, 245.00 in 2017-18 in recommended practice in comparison to 9,463 Rsha-1 and 13,926 Rsha-1 respectively in farmer's practice. It was economically observed that additional returns were 15187.00 and 16139.00 Rsha-1 in recommended practice in both the years. The benefit cost ratio also recorded higher in recommended practice with 2.01 and 2.12 as compared to 1.29 and 1.42 in farmer's practice in both the years.

The higher net returns and B: C ratio in red gram demonstration might be due to the higher grain yield and better pricing of the produce in the market.

\section{Grain yield and gap analysis of black gram}

The grain yield and gap analysis of black gram in demonstrated field's and farmer's practice is presented in table 6 . The results revealed that average grain yield of Black gram under cluster frontline demonstrations were 1160 and $1280 \mathrm{Kg} \mathrm{ha}^{-1}$ as compare to 890 and 910 $\mathrm{Kg} \mathrm{ha}{ }^{-1}$ recorded in farmer's practice and average yield increase of 30.33 and 40.65 per cent, respectively. These results also supported by Bairwa et al., (2013) and also Hiremath and Nagaraju (2010) in blackgram crop. The extension gap 270 and $380 \mathrm{Kg} \mathrm{ha}^{-1}$, technology gap 340 and $220 \mathrm{Kg} \mathrm{ha}^{-1}$ and technology index 22.6 and 17.18 was recorded.

The observed technology gap may be attributed dissimilarity in soil fertility status, rainfall distribution, disease, insect, pest infestations and weed intensity well as the change in the locations of cluster frontline demonstration sites. The technology index shows the feasibility of the variety at the farmer's field. The lower value of technology index more is the feasibility of technology. This indicates that a gap existed between technology evolved and technology adoption at farmer's field

\section{Economics analysis of black gram}

Economic performance of Black gram under cluster frontline demonstration was explained in table 7. The economic analysis results revealed that the black gram recorded higher 
total return from recommended practice (CFLD's) were 58,400.00 Rsha-1 in 201617and 69,120. 00 Rsha-1 in 2017-18 as compared to 44,500.00 Rsha $^{-1}$ and 49,140.00 Rsha-1 farmer's. Practice respectively. The net returns were 35,500.00 Rsha-1 in 2016-17 and 44,980.00 in 2017-18 in recommended practice in comparison to $17,625.00 \mathrm{Rsha}^{-1}$ and 20,240.00 Rsha $^{-1}$ respectively in farmer's practice. It was economically observed that additional returns were $17,875.00$ and $24,740.00$ Rsha-1 in recommended practice in both the years. The benefit cost ratio also recorded higher in recommended practice with 2.58 and 2.86 as compared to 1.66 and 1.70 in farmer's practice in both the years. These results in accordance with the findings of Gurumukhi and Mishra (2003), Dhaka et al., (2010) and Singh et al., (2018).

Table.1 Differences between technological intervention and farmers practices under FLD on Red gram

\begin{tabular}{|c|c|c|c|}
\hline Particulars & $\begin{array}{c}\text { Technological } \\
\text { intervention in } \\
\text { FLD }\end{array}$ & Farmers practices & Gap \\
\hline Variety & PRG-176 & Local/own seed & Full gap \\
\hline Seed rate & $7.5 \mathrm{~kg} / \mathrm{ha}$ & $10 \mathrm{~kg} / \mathrm{ha}$ & High seed rate \\
\hline $\begin{array}{l}\text { Sowing method } \\
\text { /Spacing }\end{array}$ & $\begin{array}{l}150 \quad \mathrm{X} \quad 20 \quad \mathrm{~cm}, \\
\text { sowing with seed } \\
\text { cum fertilizer drill }\end{array}$ & $\begin{array}{l}\text { Broad casting, un } \\
\text { even plant } \\
\text { population }\end{array}$ & Partial gap \\
\hline Time of Sowing & $\begin{array}{l}\text { June } 15 \text { th to } 31 \mathrm{st} \\
\text { July }\end{array}$ & $\begin{array}{l}\text { June } 15 \text { th to } 15 \text { th } \\
\text { July }\end{array}$ & Partial gap \\
\hline Seed treatment & $\begin{array}{l}\text { Seed treatment was } \\
\text { done } \\
\text { Rhiozibium }\end{array}$ & $\begin{array}{l}\text { Seed treatment was } \\
\text { not by done }\end{array}$ & Full gap \\
\hline Fertilizer Dose & $\begin{array}{l}\text { Balanced } \\
\text { fertilization as per } \\
\text { soil test values } 44 \mathrm{~kg} \\
\text { of urea in split doses } \\
\text { and } 312.5 \mathrm{~kg} \text { of SSP } \\
\text { as basal dose. }\end{array}$ & $\begin{array}{l}\text { Imbalance use of } \\
\text { fertilizer } 20 \mathrm{Kg} \text { urea } \\
\text { as basal and } 50 \mathrm{Kg} \\
\text { DAP as top dressing. }\end{array}$ & Full gap \\
\hline Weed management & $\begin{array}{l}\text { Imazethapyr 10SL } \\
75 \mathrm{~g} \text { a.i. ha- } 1 \text { at } 15-20 \\
\text { DAS. }\end{array}$ & $\begin{array}{l}\text { Manual weeding / } \\
\text { weeding with } \\
\text { bullocks }\end{array}$ & Full gap \\
\hline Plant Protection & $\begin{array}{l}\text { Neem oil @ 5ml/lit } \\
\text { and Cholrophyriphos } \\
@ 2.5 \text { ml/lit for } \\
\text { control of sucking } \\
\text { pest. }\end{array}$ & $\begin{array}{l}\text { Injudicious use of } \\
\text { and insecticides and } \\
\text { fungicides. }\end{array}$ & Full gap \\
\hline
\end{tabular}


Table.2 Differences between technological intervention and farmers practices under FLD on Black gram

\begin{tabular}{|c|c|c|c|}
\hline Particulars & $\begin{array}{c}\text { Technological } \\
\text { intervention in FLD }\end{array}$ & Farmers practices & Gap \\
\hline Variety & TBG-104 & Local/own seed & Full gap \\
\hline Seed rate & $20 \mathrm{~kg} / \mathrm{ha}$ & $22 \mathrm{~kg} / \mathrm{ha}$ & High seed rate \\
\hline $\begin{array}{l}\text { Sowing method } \\
\text { /Spacing }\end{array}$ & $\begin{array}{l}30 \text { X } 10 \mathrm{~cm} \text {, sowing } \\
\text { with seed cum fertilizer } \\
\text { drill }\end{array}$ & $\begin{array}{l}\text { Broad casting, un } \\
\text { even plant } \\
\text { population }\end{array}$ & Partial gap \\
\hline Time of Sowing & June 15 to 15 July & June 15 to 30 July & Partial gap \\
\hline Seed treatment & $\begin{array}{l}\text { Seed treatment was } \\
\text { done with } 2.5 \mathrm{gm} \text { of } \\
\text { Carbendizum and } 5 \mathrm{ml} \\
\text { of Imidacloprid per one } \\
\mathrm{kg} \text { to control sucking } \\
\text { pest and diseases up to } \\
\text { one month }\end{array}$ & $\begin{array}{l}\text { Seed treatment was } \\
\text { not done }\end{array}$ & Full gap \\
\hline Fertilizer Dose & $\begin{array}{l}\text { Balanced fertilization } \\
\text { as per soil test values } \\
44 \mathrm{~kg} \text { of urea in split } \\
\text { doses and } 312.5 \mathrm{~kg} \text { of } \\
\text { SSP as basal dose/ha }\end{array}$ & $\begin{array}{l}\text { Imbalance use of } \\
\text { fertilizer } 20 \mathrm{Kg} \text { urea } \\
\text { as basal and } 50 \mathrm{Kg} \\
\text { DAP as top dressing }\end{array}$ & Full gap \\
\hline Weed management & $\begin{array}{l}\text { Imazethapyr 10SL } 75 \mathrm{~g} \\
\text { a.i. ha }{ }^{-1} \text { at15-20 DAS. }\end{array}$ & Manual weeding & Full gap \\
\hline Plant Protection & $\begin{array}{l}\text { Neem oil @ 5ml/lit and } \\
\text { Cholrophyriphos @ } 2.5 \\
\text { ml/lit for control of } \\
\text { sucking pest. Practiced } \\
\text { Integrated measures to } \\
\text { control Yellow mosaic } \\
\text { virus like growing of } \\
\text { maize and Jowar as } \\
\text { border crops, removal } \\
\text { of weeds on bunds, } \\
\text { erecting of sticky traps } \\
\text { and finally chemical } \\
\text { control measures. }\end{array}$ & $\begin{array}{l}\text { Injudicious use of } \\
\text { and insecticides and } \\
\text { fungicides based on } \\
\text { advice of input } \\
\text { dealers }\end{array}$ & $\begin{array}{l}\text { Partial gap with high } \\
\text { cost. }\end{array}$ \\
\hline
\end{tabular}

Table.3 Differences between technological intervention and farmers practices under FLD on Chick pea

\begin{tabular}{|l|l|l|l|}
\hline Particulars & $\begin{array}{l}\text { Technological } \\
\text { intervention }\end{array}$ in & Farmers practices & Gap \\
\hline
\end{tabular}




\begin{tabular}{|c|c|c|c|}
\hline & FLD & & \\
\hline Variety & $\begin{array}{c}\text { NBeG-3 (Nandyal } \\
\text { shanaga 1) }\end{array}$ & Local/own seed & Full gap \\
\hline Seed rate & $100 \mathrm{~kg} / \mathrm{ha}$ & $120 \mathrm{~kg} / \mathrm{ha}$ & High seed rate \\
\hline $\begin{array}{l}\text { Sowing method } \\
\text { /Spacing }\end{array}$ & $\begin{array}{l}30 \times 10 \mathrm{~cm} \text {, sowing } \\
\text { with seed cum } \\
\text { fertilizer drill }\end{array}$ & $\begin{array}{l}\text { Bullock drawn drill, } \\
\text { un even plant } \\
\text { population }\end{array}$ & Partial gap \\
\hline Time of Sowing & $\begin{array}{l}\text { October 1st 15th } \\
\text { November }\end{array}$ & $\begin{array}{l}\text { October 1st 30th } \\
\text { October }\end{array}$ & Partial gap \\
\hline Seed treatment & $\begin{array}{l}\text { Seed treatment was } \\
\text { done with } 3 \mathrm{gm} \text { of } \\
\text { Carbendizum and } \\
1.5 \mathrm{gm} \text { of } \\
\text { Tibuconazole per } \\
\text { one kg seed to } \\
\text { control sucking pest } \\
\text { and diseases up to } \\
\text { one month. } \\
\text { Trichoderma @ } 5 \mathrm{gm} \\
\text { /kg of seed to } \\
\text { control wilt. }\end{array}$ & $\begin{array}{l}\text { Seed treatment was } \\
\text { done with } \\
\text { Trichoderma viride }\end{array}$ & Full gap \\
\hline Fertilizer Dose & $\begin{array}{c}\text { Balanced } \\
\text { fertilization as per } \\
\text { soil test values } 44 \mathrm{~kg} \\
\text { of urea in split doses } \\
\text { and } 312.5 \mathrm{~kg} \text { of SSP } \\
\text { as basal dose and } 50 \\
\mathrm{~kg} / \mathrm{ha} \mathrm{ZnSO}_{4} \text { as } \\
\text { basal to improve } \\
\text { quality of seed }\end{array}$ & $\begin{array}{l}\text { Imbalance use of } \\
\text { fertilizer } 20 \mathrm{Kg} \text { urea } \\
\text { as basal and } 50 \mathrm{Kg} \\
\text { DAP as top dressing. }\end{array}$ & Full gap \\
\hline Weed management & $\begin{array}{l}\text { Pendimethalin } 1 \text { litre } \\
\text { per acre as pre } \\
\text { emergence } \\
\text { application }\end{array}$ & Manual weeding & Full gap \\
\hline Plant Protection & $\begin{array}{l}\text { Practiced Integrated } \\
\text { measures to control } \\
\text { wilt and root rot like } \\
\text { summer deep } \\
\text { ploughings, } \\
\text { Following crop } \\
\text { rotation etc. }\end{array}$ & $\begin{array}{l}\text { Injudicious use of } \\
\text { and insecticides and } \\
\text { fungicides. }\end{array}$ & Full gap \\
\hline
\end{tabular}


Table.4 Grain yield and gap analysis of cluster frontline demonstrations on Red gram

\begin{tabular}{|c|c|c|c|c|c|c|c|}
\hline \multirow[t]{2}{*}{ Year } & \multirow[t]{2}{*}{$\begin{array}{c}\text { No. Of } \\
\text { Demonstrations }\end{array}$} & \multicolumn{2}{|c|}{$\begin{array}{c}\text { Average yield } \\
\mathrm{Kg} \mathrm{ha}^{-1}\end{array}$} & \multirow{2}{*}{$\begin{array}{l}\text { \% Increase in } \\
\text { Recommended } \\
\text { Practice (RP) }\end{array}$} & \multirow{2}{*}{$\begin{array}{c}\text { Extension } \\
\text { gap (Kg } \\
\left.\text { ha }^{-1}\right)\end{array}$} & \multirow{2}{*}{$\begin{array}{l}\text { Technology } \\
\text { gap } \\
\left(\mathrm{Kg} \mathrm{ha}^{-}\right)\end{array}$} & \multirow[t]{2}{*}{$\begin{array}{l}\text { Technology } \\
\text { Index }\end{array}$} \\
\hline & & $\begin{array}{r}\text { Recommended } \\
\text { practice }\end{array}$ & $\begin{array}{l}\text { Farmers } \\
\text { practice }\end{array}$ & & & & \\
\hline 2016-17 & 25 & 970 & 830 & 16.86 & 140 & 560 & 35.3 \\
\hline $2017-8$ & 25 & 1050 & 870 & 20.68 & 180 & 450 & 29.5 \\
\hline Average & 25 & 1010 & 850 & 18.82 & 160 & 490 & 32.6 \\
\hline
\end{tabular}

Table.5 Economic analysis of the cluster frontline demonstrations on Redgram

\begin{tabular}{|c|c|c|c|c|c|c|c|c|c|}
\hline \multirow[t]{2}{*}{ Year } & \multicolumn{2}{|c|}{ Total returns(Rs.ha $\left.{ }^{-1}\right)$} & \multicolumn{2}{|c|}{ Input $\operatorname{cost}\left(\right.$ Rs.ha $\left.{ }^{-1}\right)$} & \multicolumn{2}{|c|}{ Net return(Rs.ha $\left.{ }^{-1}\right)$} & \multirow{2}{*}{$\begin{array}{c}\text { Additional } \\
\text { return } \\
\text { (Rs.ha-1) } \\
\text { FLD's }\end{array}$} & \multicolumn{2}{|c|}{$\mathrm{B}: \mathrm{C}$ ratio } \\
\hline & $\begin{array}{l}\text { Recommended } \\
\text { Practice (RP) }\end{array}$ & $\begin{array}{l}\text { Farmer's } \\
\text { Practice } \\
\text { (FP) }\end{array}$ & $\begin{array}{l}\text { Recommended } \\
\text { Practice (RP) }\end{array}$ & $\begin{array}{l}\text { Farmer's } \\
\text { Practice } \\
\text { (FP) }\end{array}$ & $\begin{array}{l}\text { Recommende } \\
\text { d Practice } \\
\text { (RP) }\end{array}$ & $\begin{array}{l}\text { Farmer's } \\
\text { Practice } \\
\text { (FP) }\end{array}$ & & $\begin{array}{c}\text { Recommen } \\
\text { ded } \\
\text { Practice } \\
\text { (RP) }\end{array}$ & Practice (FP) \\
\hline $\begin{array}{l}201 \\
6- \\
17\end{array}$ & 48,985 & 41,915 & 24,335 & 32,452 & 24,650 & 9,463 & 15,187 & 2.01 & 1.29 \\
\hline $\begin{array}{l}201 \\
7- \\
18\end{array}$ & 57,225 & 47,415 & 26,980 & 33,489 & 30,245 & 13,926 & 16,319 & 2.12 & 1.42 \\
\hline $\begin{array}{l}\text { Ave } \\
\text { rag } \\
\text { e }\end{array}$ & 53,105 & 44,665 & 25,658 & 32,971 & 27,448 & 11,965 & 15,753 & 2.1 & 1.4 \\
\hline
\end{tabular}

Note: MSP of red gram @Rs.5050.00 qt-1 in 2016-17 and Rs.5450.00 qt-1in 2017-18.

Table.6 Grain yield and gap analysis of cluster frontline demonstrations on Black gram

\begin{tabular}{|r|l|r|r|r|r|r|r|}
\hline Year & $\begin{array}{l}\text { No. Of } \\
\text { Demonstrations }\end{array}$ & \multicolumn{2}{|c|}{$\begin{array}{c}\text { Average yield } \\
\text { Kg ha }^{-1}\end{array}$} & $\begin{array}{r}\text { \% Increase in } \\
\text { Recommended } \\
\text { Practice (RP) }\end{array}$ & $\begin{array}{r}\text { Extension } \\
\text { gap (Kg } \\
\left.\text { ha }^{-1}\right)\end{array}$ & $\begin{array}{r}\text { Technology } \\
\text { gap (Kg ha } \\
\text { 1) }\end{array}$ & $\begin{array}{r}\text { Technology } \\
\text { Index }\end{array}$ \\
\cline { 2 - 8 } & & $\begin{array}{r}\text { Recommended } \\
\text { practice }\end{array}$ & $\begin{array}{r}\text { Farmers } \\
\text { practice }\end{array}$ & & & & \\
\hline $\mathbf{2 0 1 6 - 1 7}$ & 25 & 1160 & 890 & 30.33 & 270 & 340 & 22.6 \\
\hline $\mathbf{2 0 1 7 - 8}$ & 35 & 1280 & 910 & 40.65 & 380 & 220 & 17.18 \\
\hline Average & 30 & 1220 & 900 & 35.6 & 320 & 280 & 18.66 \\
\hline
\end{tabular}


Table.7 Economic analysis of the cluster frontline demonstrations on Black gram

\begin{tabular}{|c|c|c|c|c|c|c|c|c|c|}
\hline \multirow[t]{2}{*}{ Year } & \multicolumn{2}{|c|}{$\begin{array}{l}\text { Total } \\
\text { returns(Rs.ha-1 }\end{array}$} & \multicolumn{2}{|c|}{ Input cost(Rs.ha-1) } & \multicolumn{2}{|c|}{ Net return(Rs.ha-1) } & \multirow{2}{*}{$\begin{array}{l}\text { Addition } \\
\text { al return } \\
\text { (Rs.ha-1) } \\
\text { FLD's }\end{array}$} & \multicolumn{2}{|l|}{$\mathrm{B}: \mathrm{C}$ ratio } \\
\hline & $\begin{array}{l}\text { Recomme } \\
\text { nded } \\
\text { Practice } \\
\text { (RP) }\end{array}$ & $\begin{array}{l}\text { Farmer's } \\
\text { Practice } \\
\text { (FP) }\end{array}$ & $\begin{array}{l}\text { Recommended } \\
\text { Practice (RP) }\end{array}$ & $\begin{array}{l}\text { Farmer's } \\
\text { Practice } \\
\text { (FP) }\end{array}$ & $\begin{array}{l}\text { Recommend } \\
\text { ed Practice } \\
\text { (RP) }\end{array}$ & $\begin{array}{l}\text { Farmer's } \\
\text { Practice } \\
\text { (FP) }\end{array}$ & & $\begin{array}{l}\text { Recommen } \\
\text { ded } \\
\text { Practice } \\
\text { (RP) }\end{array}$ & $\begin{array}{l}\text { Farmer' } \\
\text { s } \\
\text { Practice } \\
\text { (FP) }\end{array}$ \\
\hline $\begin{array}{l}201 \\
6-17\end{array}$ & 58,400 & 44,500 & 22,500 & 26,875 & 35,500 & 17,625 & 17,875 & 2.58 & 1.66 \\
\hline $\begin{array}{l}201 \\
7-18\end{array}$ & 69,120 & 49,140 & 24,140 & 28,900 & 44,980 & 20,240 & 24,740 & 2.86 & 1.70 \\
\hline $\begin{array}{l}\text { Ave } \\
\text { rage }\end{array}$ & 63,560 & 46,820 & 23,320 & 27,888 & 40,240 & 18,933 & 21,308 & 2.72 & 1.68 \\
\hline
\end{tabular}

Note: MSP of black gram @Rs.5000.00 qt-1 in 2016-17 and Rs.5400.00 qt-1in 2017-18.

Table.8 Grain yield and gap analysis of cluster frontline demonstrations Chick pea

\begin{tabular}{|r|l|r|r|r|r|r|r|}
\hline Year & $\begin{array}{l}\text { No. Of } \\
\text { Demonstrations }\end{array}$ & \multicolumn{2}{|c|}{$\begin{array}{c}\text { Average yield } \\
\mathrm{Kg} \mathrm{ha}^{-1}\end{array}$} & $\begin{array}{r}\text { \% Increase in } \\
\text { Recommended } \\
\text { Practice (RP) }\end{array}$ & $\begin{array}{r}\text { Extension } \\
\text { gap (Kg } \\
\left.\text { ha }^{-1}\right)\end{array}$ & $\begin{array}{r}\text { Technology } \\
\text { gap (Kg ha } \\
1\end{array}$ & $\begin{array}{r}\text { Technology } \\
\text { Index }\end{array}$ \\
\cline { 3 - 9 } & & $\begin{array}{r}\text { Recommended } \\
\text { practice }\end{array}$ & $\begin{array}{r}\text { Farmers } \\
\text { practice }\end{array}$ & & & & \\
\hline $\mathbf{2 0 1 6 - 1 7}$ & 25 & 850 & 720 & 18.06 & 130 & 450 & 34.61 \\
\hline $\mathbf{2 0 1 7 - 8}$ & 35 & 950 & 810 & 21.9 & 140 & 350 & 26.92 \\
\hline Average & 30 & 900 & 765 & 19.93 & 135 & 400 & 30.76 \\
\hline
\end{tabular}

Table.9 Economic analysis of the cluster frontline demonstrations on Chick pea

\begin{tabular}{|l|l|l|l|l|l|l|l|l|l|}
\hline Year & $\begin{array}{l}\text { Total } \\
\text { returns(Rs.ha-1 }\end{array}$ & \multicolumn{2}{l|}{ Input cost(Rs.ha-1) } & Net return(Rs.ha-1) & $\begin{array}{l}\text { Additional } \\
\text { return } \\
\text { (Rs.ha-1) } \\
\text { FLD's }\end{array}$ & B:C ratio \\
\hline & $\begin{array}{l}\text { Recomme } \\
\text { nded } \\
\text { Practice } \\
\text { (RP) }\end{array}$ & $\begin{array}{l}\text { Farmer's } \\
\text { Practice } \\
\text { (FP) }\end{array}$ & $\begin{array}{l}\text { Recommended } \\
\text { Practice (RP) }\end{array}$ & $\begin{array}{l}\text { Farmer's } \\
\text { Practice } \\
\text { (FP) }\end{array}$ & $\begin{array}{l}\text { Recommend } \\
\text { ed Practice } \\
\text { (RP) }\end{array}$ & $\begin{array}{l}\text { Farmer's } \\
\text { Practice } \\
\text { (FP) }\end{array}$ & & $\begin{array}{l}\text { Recomme } \\
\text { nded } \\
\text { Practice } \\
\text { (RP) }\end{array}$ & $\begin{array}{l}\text { Farmer' } \\
\text { s } \\
\text { Practice } \\
\text { (FP) }\end{array}$ \\
\hline $\begin{array}{l}\mathbf{2 0 1} \\
\mathbf{6 - 1 7}\end{array}$ & 34,000 & 28,800 & 17,500 & 19,750 & 16,500 & 9,050 & 7,450 & 1.94 & 1.46 \\
\hline $\begin{array}{l}\mathbf{2 0 1} \\
\mathbf{7 - 1 8}\end{array}$ & 41,800 & 35,640 & 18,750 & 20,625 & 23,050 & 15,015 & 8,035 & 2.23 & 1.73 \\
\hline $\begin{array}{l}\text { Ave } \\
\text { rage }\end{array}$ & 37,900 & 32,200 & 18,125 & 20,188 & 19,775 & 12,033 & 7,743 & 2.09 & 1.59 \\
\hline
\end{tabular}

Note: MSP of Chick pea @ Rs.4000.00 qt-1 in 2016-17 and Rs.4400.00 qt-1in 2017-18 


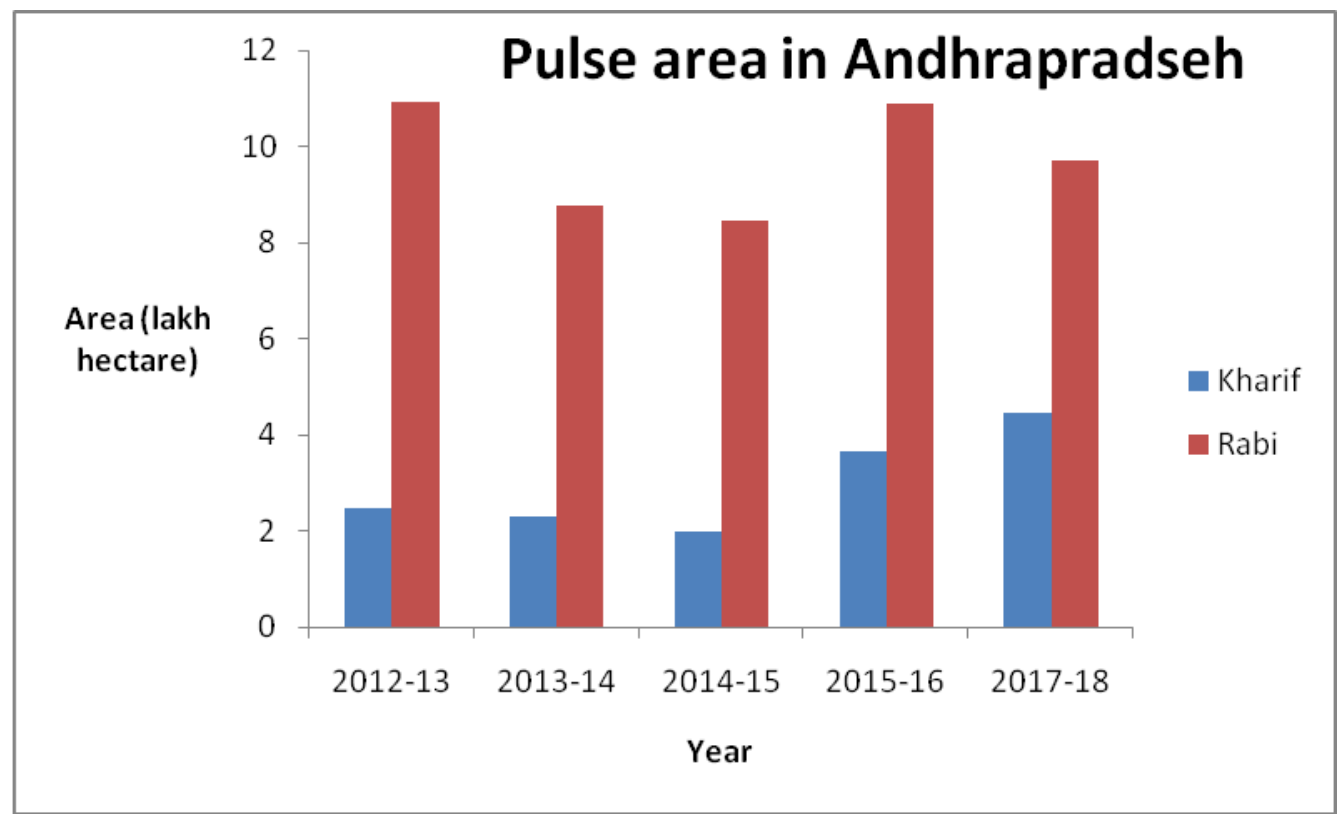

\section{Grain yield and gap analysis of chick pea}

The grain yield and gap analysis of Chick pea in demonstrated field's and farmer's practice is presented in table 8 . The results revealed that average grain yield of chick pea under cluster frontline demonstrations were 850 and $950 \mathrm{Kg} \mathrm{ha}^{-1}$ as compare to 720 and $810 \mathrm{Kg}$ ha $^{-1}$ recorded in farmer's practice and average yield increase of 18.06 and 21.9 per cent, respectively. The above finding was accordance with Lakshmi et al., (2017). The extension gap 130 and $140 \mathrm{Kg} \mathrm{ha}{ }^{-1}$, technology gap 450 and $350 \mathrm{Kg} \mathrm{ha}^{-1}$ and technology index 34.61 and 26.92 was recorded.

\section{Economics analysis of chick pea}

Economic performance of chick pea under cluster frontline demonstration was depicted in table 9. The economic analysis results revealed that the red gram recorded higher total return from recommended practice (CFLD's) were 34,000.00 $\mathrm{Rsha}^{-1}$ in 2016-17 and 41,800.00 $\mathrm{Rsha}^{-1}$ in 2017-18 as compared to $28,800.00 \mathrm{Rsha}^{-1}$ and $35,640.00 \mathrm{Rsha}^{-1}$ farmer's. Practice respectively. The net returns were $16,500.00 \mathrm{Rsha}^{-1}$ in 2016-17 and $23,050.00$ in 2017-18 in recommended practice in comparison to 9,050.00 Rsha-1 and 15,015.00 Rsha-1respectively in farmer's practice. It was economically observed that additional returns were $7,450.00$ and 8035.00 Rsha-1 in recommended practice in both the years. The benefit cost ratio also recorded higher in recommended practice with 1.94 and 2.23 as compared to 1.46 and 1.66 in farmer's practice in both the years.

It is concluded that the CFLD programme is an effective tool for increasing the production and productivity of pulses and changing the knowledge, attitude and skill of farmers. The per cent increment in yield of pulses to the extent of 16.86 to 20.68 in Red gram and 30.33 to 40.65 in Black gram and 18.06 to 21.90 in Chick pea FLDs over the farmers practice created greater awareness and motivated the other farmers to adopt the improved package of practices of pulses. These demonstrations also built the relationship and confidence between farmers and scientists. The beneficiary farmers of FLDs also play an important role as source of information and quality seeds for wider 
dissemination of the high yielding varieties of pulses for other near by farmers.

\section{Acknowledgement}

Krishi Vigyan Kendra, Banavasi is thankful to the Director, ICAR-ATARI, Zone-X, Hyderabad for providing funds for conducting the CFLDs and farmers who always show faith in the Krishi Vigyan Kendra.

\section{References}

Annonymous(2011) Agricultural statistics at a glance. DAC Government of India. p. 118.

Bairwa, R. K., Verma, S. R., Chayal, K. and Meena, N. L. (2013). Popularization of Improved Black gram Production Technology through Front line demonstration in humid southern plain of Rajasthan, Indian Journal of Extension Education and R.D. 21: 97101.

Dhaka, B.L, Meena, B.S. and Suwalka, R. L. (2010). Popularization of improved maize technology through frontline demonstration in South-eastern Rajasthan. Journal of Agricultural Sciences (1): 39-42.

D. Vijaya Lakshmi, P. Vijay Kumar and C. Padma Veni. Impact of Cluster Frontline Demonstrations to Transfer of Technologies In Pulse Production Under NFSM. Bull. Env. Pharmacol. Life Sci., Vol 6 Special issue 1, 2017:
418-421

Gurumukhi, D. R, and Mishra, S. 2003. Sorghum front line demonstration - A success story. Agriculture Extension Review, 15(4): 22-23.

Hiremath, S.M and Nagaraju, M.V. (2010). Evaluation of on front line demonstrations on the yield of chilli, Karnataka J. Agric. Sci., 23 (2): 341342.

Sumathi, P. (2012). Role of front line demonstrations on transfer of pulses production Technologies in Vellore district of Tamil Nadu Agriculture Update Volume7 issue 2(FebruaryMarch) pp 147-150

Singh S. P., K. K. Paikra and Chanchala Rani Patel. 2018. Performance of cluster frontline demonstration on productivity and profitability of Blackgram (Vigna mungo) in Raigarh District of Chhattisgarh, India. Int.J.Curr. Microbiol.App.Sci. 7(06): 1325-1330

Singh, G., Dhaliwal, N.S., Singh, J. and Sharma, K. (2011). Effect of frontline demonstrations on enhancing productivity of mustard. Asian J Soil Sci6: 230-33.

Yadav, D.B., Kamboj, B.K. and Garg, R.B. (2004). Increasing the productivity and profitability of sunflower through frontline demonstrations in irrigated agro-ecosystem of eastern Haryana. J Agron20: 33-35.

\section{How to cite this article:}

Jayalakshmi Mitnala, G. Prasad Babu, K. Ragavendra Chowdary, B. Vijayabhinandana and Subba Rao, M. 2018. Impact of Cluster Frontline Demonstrations (CFLDs) on Pulse Production Productivity, Profitability and Transfer of Technologies in Kurnool District of Andhra Pradesh, India. Int.J.Curr.Microbiol.App.Sci. 7(12): 937-947. doi: https://doi.org/10.20546/ijcmas.2018.712.117 